\title{
ANALISIS LAPORAN AKUNTABILITAS KINERJA INSTANSI PEMERINTAH PADA DINAS PEKERJAAN UMUM KABUPATEN MINAHASA
}

\author{
Jenefer Hermina Worotikan ${ }^{1}$,Jullie J. Sondakh ${ }^{2}$, Hendrik Gamaliel ${ }^{3}$ \\ 1,2,3 Jurusan Akuntansi, Fakultas Ekonomi dan Bisnis, Universitas Sam Ratulangi, Jl.Kampus Bahu, Manado, \\ 95115, Indonesia \\ E-mail : Worotikan18@gmail.com
}

\begin{abstract}
Department of public work of Minahasa district is one of the agencies within the scope of governmental of Minahasa district which has responsibility to compose accountabilities Performance peport of Government instance. LAKIP is a form of the government accountability on performance implementation which is carried out within a year estimates and as on of the manifestation of good governance. The purpose of this study was to analyze what factors caused the format of LAKIP formulation to the DPU not to fulfill the suitability of the elements of the formatting format in accordance with the Regulation of the Minister of State for Administrative Reform and Bureaucratic Reform number 29 year 2010 consisting of executive summary, introduction, planning and agreement performance, performance accountability, strategic plan, annual performance plan form (CTR), key performance indicators (IKU), performance agreement form, closing, attachments. The elements that are not yet in accordance with the regulations are the main performance indicators, covers and attachments. The methods of data collection which is used are interviews and documentation. The method of analyses of data which used is descriptive qualitative. The results of this study indicate that the format of the 2016 Minahasa DPU LAKIP drafting has largely compiled in accordance with PERMENPAN number 29 year 2010 but there are still elements in the format of the DPU LAKIP preparation that are not in accordance with the regulation.
\end{abstract}

Keywords : LAKIP, good governance, accountability.

\section{PENDAHULUAN}

Lawedalu, Kalangi, dan Warongan (2016:66), mengungkapkan bahwa otonomi di dalam daerah mengharapkan pemerintahan di daerah tersebut mampu menyalurkan layanan untuk masyarakt sesuai dengan peraturan yang telah ditetapkan tentang pelayanan masyarakat agar terciptanya tata kelola yang sesuai dengan keinginan (good governance). Menurut Mahsun (2013:20), good governance merupakan bentuk pertanggungjawaban pemerintah kepada organisasi sektor publik untuk meningkatkan kesejahteraan masyarakat dan menjalankan aspek-aspek fungsional dari pemerintahan secera efektif dan efesien. Pertanggungjawaban dan pelaporan segala aktivitas instansi pemerintah baik pusat maupun daerah, dituangkan dalam LAKIP atau Laporan Akuntabilitas Kinerja Instansi Pemerintah. Berdasarkan Peraturan Menteri Negara Pendayagunaan Aparatur Negara dan Reformasi Birokrasi Nomor 29 tahun 2010 tentang pendoman penyusunan penetapan kinerja dan pelaporan akuntabilitas kinerja instansi pemerintah yang menjadi pendoman penyusunan dan acuan penyusunan LAKIP membuat pelaporan demikian untuk alat ukur dalam pencapaian keberhasilan kinerja. Dibuatnya pembentukan dan penyajian LAKIP adalah untuk meciptakan pertangungjawaban kinerja instansi pemerintahan kepada pejabat-pejabat yang memberikan mandat atau amanat (Santoso, 2013).

Dinas Pekerjaan Umum (DPU) merupakan salah satu instansi pemerintah di Kabupaten Minahasa. Dinas ini memiliki fungsi sebagai berikut: a) pengawasan dan pengendalian sumber daya air, b) pembangunan dan pengawasan perkotaan dan perdesaan, c) 
pembangunan dan pengawasan permukiman kawasan siap bangun (kasiba), d) pelaksanaan pengaturan, pembangunan dan pengawasan perumahan, e) pelaksanaan pengaturan, pemberdayaan dan pembangunan jasa konstruksi, f) pelaksanaan kegiatan ketatausahaan, g) penyusunan dan penyampaian laporan kegiatan. DPU Kabupeten Minahasa dalam mempertanggungjawabkan tugas dan fungsi yang ada, diwajibkan untuk membuat laporan dalam bentuk LAKIP. Tujuan LAKIP pada DPU Kabupaten Minahasa adalah untuk mempertanggungjawabkan kinerja instansi secara terukur dalam mencapai tujuan/sasaran strategis yang telah ditetapkan. Dalam pembuatan LAKIP, acuan dari DPU Kabupaten Minahasa yaitu PERMENPAN No 29 Tahun 2010 yang digunakan sebagai acuan bagi setiap instansi pemeritah dalam menyusun dokumen penetapan kinerja dan laporan akuntabilitas kinerja instansi agar optimal.

PERMENPAN No 29 Tahun 2010 memiliki 10 unsur format penyusunan LAKIP yaitu Ikhtisar Eksekutif, Pendahuluan, Perencanaan dan Perjanjian Kinerja, Akuntabilitas Kinerja, Rencana Strategis, Formulir Rencana Kinerja Tahunan (RKT), Indikator Kinerja Utama (IKU), Formulir Perjanjian Kinerja, Penutup, Lampiran. Namun dalam prakteknya, dari hasil pengamatan pada LAKIP DPU Kabupaten Minahasa tahun 2016 terdapat 1 unsur yang tidak sesuai yaitu IKU dan 2 unsur belum sesuai dengan peraturan yaitu penutup dan lampiran. Dinas ini tidak menyusun format sesuai regulasi pendukung yaitu Peraturan Menteri Negara Pendayagunaan Aparatur Negara dan Reformasi Birokrasi Nomor 29 Tahun 2010 tentang Pedomanan Penyusunan Penetapan Kinerja dan Pelaporan Akuntabilitas Kinerja Instansi Pemerintah sebagai tindak lanjut TAP MPR RI Nomor XI/MPR/1998 tentang Penyelenggaraan Negara yang Bersih dan Bebas Korupsi, Kolusi dan Nepotisme.

\section{TINJAUAN PUSTAKA}

Organisasi Sektor Publik. Mahmud, Sondakh, dan Budiarso (2016:694) mengungkapkan organisasi sektor publik pada umumnya berupa lembaga-lembaga negara atau pemerintahan atau organisasi yang memiliki keterkaitan dengan keuangan negara. Organisasi ini merupakan suatu kesatuan yang pusat kegiatannya focus pada kepentingan masyarakat, dan olehkarenanya organisasi sector public tidak mementingkan laba dan menjadikannya sebagai tujuan dalam organisasi tetapi lebih kepada kepuasan masyarakat. Kemudian dikatakan Tambariki, Karamoy, dan Tangkuman (2018:551) bahwa organisasi sektor public bukan hanya dibuat untuk mennghasilkan laba akan tetapi dilaksanakan untuk menyediakan pelayanan untuk kepentingan masyarakat umum. Tujuan organisasi meletakkan kerangka prioritas untuk memfokuskan arah semua program dan aktivitas lembaga dalam melaksanakan misi lembaga.

Pengertian Kinerja dan Pengukuran Kinerja. Moeheriono (2012:95) mengungkapkan kinerja atau performance merupakan gambaran mengenai tingkat pencapaian pelaksanaan suatu program kegiatan atau kebijakan dalam mewujudkan sasaran, tujuan, visi dan misi organisasi yang dituangkan melalui perencanaan strategis suatu organisasi. Maka demikian dapat disimpulkan bahwa, kinerja adalah hasil kerja yang dilakukan oleh seseorang/individu atau kelompok orang untuk melakukan suatu kegiatan secara bertanggung jawab atau sesuai dengan tanggung jawabnya dengan hasil seperti yang diharapkan.

Indikator Kinerja. Indikator kinerja merupakan suatu pengukuran dalam menentukan kinerja organisasi baik secara kualitatif dan kuantitatif didalamnya terdiri atas seberapa besar capaian dari suatu program kerja yang telah disusun dan ditetapkan sebagai suatu sasaran dan tujuan didalam organisasi pemerintah. Maka dari itu indicator diharuskan memberikan perhitungan dan pengukuran kemudian dijadilan sebagai dasar dalam penilaian dan sebagai pengambaran terhadap tingkat kinerja organisasi termasuk didalamnya untuk perencanaan dan pelaksanaannya. Jika tidak menggunakan indicator kinerja akan kesulitan dalam 
melaksanakan penilaian terhadap tingkat keberhasilan didalam indicator masukan (input), keluaran (output), hasil (outcome), manfaat (benefit), dan dampak (impact).

Komponen Rencana Kinerja. Berikut komponen perencanaan kinerja:

1. Sasaran. Dalam rencana ini dimaksudkan bagaimana pembuatan dokumen renstra yang setelahmya dilakukan identifikasi apa yang harus dilakukan dan dilaksanakan didalam tahun yang telah ditentukan diikuti dengan rencana tingkat pencapaiannya.

2. Indikator Kinerja Sasaran. Rencana IKU atau indikator kinerja sasaran merupakan suatu pengukuran secara kuantiti dengan penggambaran variable dengan kata lain merupakan pengukuran untuk mencapa sasaran yang telah dibuat. Di dalam IKU digambarkan seberapa besar outcome yang harus dihasilkan dan dicapai.

3. Program. Merupakan rencana yang adalah susunan kegiatan yang akan dilakukan didalam tahun yang akan berjalan didalam pencapaian sasaran yang sudah di buat.

4. Kegiatan. Untuk rencana kinerja diperlukan kegiatan yang merupakan tindakan yang secara real (kenyataan) yang dilaksanakan pada jangka waktu yang telah ditetapkan dan dilakukan sesuai dengan ketentuan yang telah oleh unit kerja dengan pemanfaatan sumberdaya. Untuk perencanaan kegiatan diperlukan indictor kinerja kegiatan juga perencanaan pencapaiannya. Adapun indikator tersebut secara langsung atau tidak langsung dapat mengindikasikan sejauh mana keberhasilan pencapaian sasaran.

Evaluasi Kinerja. Evaluasi kinerja kegiatan menunjukan capaian kinerja suatu unit instansi pemerintah dalan suatu kurun waktu tertentu. Menurut Lembaga Administrasi Negara (2003:25), dalam evaluasi kinerja dilakukan analisis efesien dengan cara membandingkan antara output dengan input baik untuk rencana maupun realisasi. Evaluasi kinerja merupakan alat yang digunakan oleh instansi pemerintah atau organisasi tertentu untuk menilai kinerja para aparatur yang lamban. Evaluasi kinerja untuk memotivasi para aparatur untuk meningkatkan kinerjanya dan melakukan perbaikan pada waktu mendatang.

\section{Akuntabilitas Kinerja Instansi Pemerintah}

Akuntabilitas. Menurut Lukito, Penny, dan Kusumastuti (2014:2), akuntabilitas merupakan sebuah wujud dalam kewajiban penyediaan penyelenggaraan didalam setiap kegiatan organisasi sector public didalam mendapakan penjelasan dan pertanggungjawababn semua yang bersangkutan dengan tiap program yang telah diselengarakan dan untuk semua keputusan dan prosedur yang dilaksanakan serta dengan tanggungjawab dari suatu kegiatan yang telah diselesaikan.

Pengertian Akuntabilitas Kinerja Instansi Pemerintah. Akuntabilitas kinerja instansi pemerintah, yang selanjutnya disingkat AKIP adalah perwujudan kewajiban suatu instansi pemerintah untuk mempertanggungjawabkan keberhasilan dan kegagalan pelaksanaan misi organisasi dalam mencapai sasaran dan tujuan yang telah ditetapkan melalui sistem pertanggungjawaban secara periodik. Akuntabilitas Kinerja juga perwujudan kewajiban suatu instansi pemerintah untuk mempertanggungjawabkan keberhasilan/kegagalan pelaksanaan misi organisasi dalam mencapai tujuan-tujuan dan sasaran-sasaran yang telah ditetapkan melalui alat pertanggungjawaban secara periodik.

Laporan Akuntabilitas Kinerja Instansi Pemerintah. Pelaporan kinerja didalam pemerintahan di Indonesia biasanya menggunakan laporan akuntabilitas kinerja instansi pemerintah atau yang di singkat dengan LAKIP yang digunakan untuk media pertanggungjawaban di dalam instansi pemerintahan. Laporan ini dibuat setiap tahun untuk pelaporan pertanggungjawaban kinerja suatu instansi didalam pencapaian sasaran yang telah disusun dan di tetapkan. 
Format dan Isi LAKIP. LAKIP menyajikan uraian tentang kinerja instansi pemerintah dalam arti keberhasilan dan kegagalan pencapaian sasaran tujuan instansi pemerintah. Format LAKIP terdiri dari (PERMENPAN:2010) :

a. Ikhtisar Eksekutif (Executive Summary). Pada bagian ini disajikan tujuan dan sasaran yang telah ditetapkan dalam rencana strategis serta sejauh mana instansi pemerintah mencapai tujuan dan sasaran utama tersebut, serta kendala-kendala yang dihadapi dalam pencapaiannya. Disebutkan pula langkah-langkah apa yang telah dilakukan untuk mengatasi kendala tersebut dan langkah antisipatif untuk menanggulangi kendala yang mungkin akan terjadi pada tahun mendatang.

b. Bab I - Pendahuluan. Dalam bab ini diuraikan mengenai gambaran umum organisasi yang melaporkan dan sekilas pengantar lainnya.

c. Bab II - Perencanaan dan Perjanjian Kinerja. Dalam bab ini di uraikan mengenai beberapa hal penting dalam perencanaan dan perjanjian kinerja (dokumen penetapan kinerja). Dokumen penetapan kinerja tersebut berupa :

1. Rencana strategis. Pada bagian ini berisi uraian singkat tentang rencana strategis instansi mulai dari visi, misi, tujuan, sasaran.

2. Formulir indikator kinerja utama (IKU). Formulir IKU berisikan sasaran strategis serta indikator sasaran disertai cara perhitungan untuk mengukur capaian indikator sasaran.

3. Rencana kinerja tahunan (RKT). Formulir RKT berisi mengenai sasaran strategis dari suatu instansi sesuai dengan indikator kinerja atas sasaran strategis dari instansi.

4. Perjanjian kinerja. Formulir perjanjian kinerja berisikan target tahunan dari setiap sasaran dan indikator sasaran.

d. Bab III - Pertanggungjawaban Kinerja. Menguraikan kesuksesan dan kegagalan, target hasil kinerja, evaluasi dan analisis pertanggungjawaban kinerja, yang di dalamnya menjabarkan secara sistematis pengambilan langkah antisipatif yang harus diambil, halangan-halangan, dan persoalan yang harus dihadapi.

e. Bab IV - Penutup. Menjelaskan mengenai strategi pemecahan masalah yang akan dilakukan di tahun mendatang, permasalahan dan hambatan yang berkaitan dengan kinerja instansi yang bersangkutan serta kegagalan dan keberhasilan yang dialami.

f. Lampiran-lampiran. Menjabarkan penjelasan selanjutnya tentang, gambar, sarana prasarana, aspek pendukung seperti SDM, metode, perhitungan-perhitungan dan aspek lain dan data yang relevan sebaiknya jangan dijabarkan dalam bentuk teks laporan, tetapi dijabarkan pada lampiran.

Penelitian Terdahulu. Ada beberapa acuan dalam penulisan penelitian ini yang dipakai untuk mempertimbangkan didalam pelaksanaan penyusunan penelitian ini. Diantaranya adalah penelitian yang dilaksanakan oleh, Wulansuci (2017) terkait Analisis Laporan Akuntabilitas Kinerja Instansi Pemerintah berdasarkan Peraturan Menteri Negara Pendayagunaan Aparatur Negara dan Reformasi Birokrasi Nomor 29 Tahun 2010 pada Dinas Pekerjaan Umum dan Perumahan Kabupaten Sleman. Pada penelitian yang di lakukan Santoso (2013) terkait Analisis Laporan Akuntabilitas Kinerja pada Dinas Kebudayaan dan Pariwisata Provinsi Sulawesi Utara. Pada penelitian yang dilakukan Mangandar (2012) terkait Analisis Terhadap Penyusunan, Pengukuran, Pengevaluasian Kinerja Pada Kementerian Energi dan Sumber Daya Mineral Tahun 2010 (Perspektif Penerapan Akuntabilitas Instansi Pemerintah).

\section{METODE PENELITIAN}

Jenis Penelitian. Penelitian ini menggunakan metode penelitian kualitatif dengan pendekatan deskriptif. Penelitian kualitatif merupakan penelitian yang didesain secara umum untuk objek kajian yang tidak terbatas dan tidak menggunakan metode ilmiah menjadi patokan (Imbang, Pontoh, dan Gamaliel, 2018:385). 
Tempat dan Waktu Penelitian. Penelitian ini dilakukan pada Dinas Pekerjaan Umum Kabupaten Minahasa. Jangka waktu penyusunan penelitian ini dilakukan dari bulan Juni 2018 sampai pada bulan Agustus 2018.

\section{Jenis, Sumber dan Metode Pengumpulan Data}

Jenis Data. Jenis data kualitatif didalam penelitian ini berupa :

1. Hasil wawancara

a. Nofry W. Lontaan, ST (Kepala Dinas Pekerjaan Umum)

b. Juliana Jennie Senduk, S.Sos (Sub Bagian Program, Keuangan dan pelaporan)

c. Boy Roy Tampi (Sub Bagian Kepegawaian, Umum dan Perlengkapan).

Hasil wawancara ini digunakan untuk memperoleh data tentang gambaran umum instansi mengenai faktor-faktor yang menyebabkan ketidaksesuaian beberapa unsur format penyusunan pada LAKIP Dinas Pekerjaan Umum Kabupaten Minahasa tahun 2016 dengan PERMENPAN no 29 tahun 2010.

2. Hasil Dokumentasi yaitu LAKIP Dinas Pekerjaan Umum Kabupaten Minahasa tahun 2016. Digunakan untuk meneliti dan menganalisa data mengenai ketidaksesuaian unsurunsur format penyusunan LAKIP pada Dinas Pekerjaan Umum Kabupaten Minahasa sesuai dengan rumusan masalah dan tujuan penelitian yang ada.

Sumber Data. Didalam penyusunan penelitian ini, sumber data yang dipakai yaitu data primer. Data ini merupakan data yang didapatkan dengan cara melakukan wawancara langsung dengan sumber asli.

\section{Metode Pengumpulan Data}

1. Teknik wawancara. Untuk pengumpulan data dalam teknik wawancara, yaitu dengan mengadakan tanya jawab langsung kepada responden atau bidang yang terkait dengan data yang diperlukan pada Dinas Pekerjaan Umum Kabupaten Minahasa, diantaranya adalah :

a. Nofry W. Lontaan, ST (Kepala Dinas Pekerjaan Umum)

b. Juliana Jennie Senduk, S.Sos (Sub Bagian Program, Keuangan dan pelaporan)

c. Boy Roy Tampi (Sub Bagian Kepegawaian, Umum dan Perlengkapan).

Metode wawancara ini digunakan untuk memperoleh data tentang gambaran umum Dinas Pekerjaan Umum Kabupaten Minahasa mengenai faktor-faktor yang menyebabkan ketidaksesuaian beberapa unsur format penyusunan LAKIP tahun 2016 pada instansi tersebut sesuai dengan acuan pada PERMENPAN No 29 Tahun 2010.

2. Teknik Dokumentasi. Dokumentasi adalah suatu metode pengumpulan data dengan cara mengumpulkan dokumen yang berkaitan dengan penelitian yang dilakukan. Metode ini digunakan untuk memperoleh LAKIP DPU Kabupaten Minahasa Tahun 2016.

Metode dan Proses Analisis. Metode analisis data yang digunakan adalah metode deskriptif bersifat sistematis, terencana dan terstruktur sejak awal penelitian. Metode deskriptif merupakan suatu penelitian yang bertujuan untuk menggambarkan keadaan objek yang diteliti berdasarkan fakta-fakta yang ada dengan cara mengumpulkan, mengolah, dan menganalisis berbagai macam data sehingga dapat ditarik kesimpulan (Alou, Ilat, dan Gamaliel, 2017:141). Adapun langkah-langkah untuk menganalisis data dalam penelitian ini adalah :

1. Langkah pertama pengumpulan data di lokasi penelitian.

2. Proses Analisis, merupakan kajian yang dilakukan dengan menyesuaikan tujuan dan rumusan masalah yang ada diantaranya : 
a. Menguraikan unsur-unsur LAKIP Tahun 2016 yang ada di DPU Kabupaten Minahasa dan PERMENPAN No 29 Tahun 2010.

b. Menganalisis unsur-unsur yang tidak sesuai dan unsur-unsur yang sesuai pada LAKIP DPU Kabupaten Minahasa Tahun 2016 dengan membuat tabel perbandingan serta membuat hasil temuan pada tabel penelitian.

c. Menganalisa faktor-faktor yang menyebabkan ketidaksesuaian unsur-unsur format penyusunan LAKIP DPU Kabupaten Minahasa dari data hasil wawancara kepada bagian-bagian yang menangani LAKIP DPU Kabupaten Minahasa.

d. Dari hasil perbandingan antara LAKIP DPU Kabupaten Minahasa tahun 2016 dan PERMENPAN No 29 Tahun 2010 dan hasil analisa wawancara tersebut ditarik kesimpulan terkait faktor yang menyebabkan ketidaksesuain unsur-unsur format penyusunan pada LAKIP DPU Kabupaten Minahasa dan Peraturan Menteri Negara Pendayagunaan Aparatur Negara dan Reformasi Birokrasi Nomor 29 tahun 2010.

\section{HASIL PENELITIAN DAN PEMBAHASAN}

\subsection{Hasil Penelitian}

Objek yang menjadi tempat penelitian ini adalah pada kantor Dinas Pekerjaan Umum Kabupaten Minahasa.

LAKIP DPU dan PERMENPAN. Berdasarkan Peraturan Menteri Negara Pendayagunaan Aparatur Negara dan Reformasi Birokrasi Nomor 29 tahun 2010, LAKIP menyajikan uraian tentang kinerja instansi pemerintah dalam arti keberhasilan dan pencapaian sasaran tujuan instansi pemerintah. Berikut ini adalah uraian mengenai unsur-unsur format LAKIP yang ada dalam PERMENPAN dan DPU Kabupaten Minahasa :

1. Unsur-unsur LAKIP pada PERMENPAN No 29 Tahun 2010.

a. Ikhtisar Eksekutif

b. Pendahuluan

c. Perencanaan dan Perjanjian Kinerja

d. Akuntabilitas Kinerja

e. Rencana Strategis

f. Formulir Rencana Kinerja Tahunan (RKT)

g. Indikator Kinerja Utama (IKU)

h. Formulir Perjanjian Kinerja

i. Penutup

j. Lampiran

2. Unsur-unsur LAKIP pada DPU Kabupaten Minahasa

a. Ikhtisar Eksekutif

b. Pendahuluan

c. Perencanaan dan Perjanjian Kinerja

d. Akuntabilitas Kinerja

e. Rencana Strategis

f. Formulir Rencana Kinerja Tahunan (RKT)

g. Formulir Perjanjian Kinerja

h. Penutup

i. Lampiran

Perbandingan Unsur-Unsur Pada LAKIP DPU Kabupaten Minahasa dan PERMENPAN. Format LAKIP pada PERMENPAN terdiri dari Ikhtisar Eksekutif, Pendahuluan, Perencanaan dan Perjanjian Kinerja, Akuntabilitas Kinerja, Rencana Strategis, Formulir Rencana Kinerja Tahunan (RKT), Indikator Kinerja Utama (IKU), Formulir Perjanjian Kinerja, Penutup, Lampiran. Sampai saat ini PERMENPAN merupakan Pedoman 
Penyusunan Penetapan Kinerja dan Pelaporan Akuntabilitas Kinerja Instansi Pemerintah yang masih digunakan sebagai salah satu pedoman dalam pelaporan kinerja di instansi pemerintah. DPU Kabupaten Minahasa dalam hal ini sebagai salah satu instansi pemerintah di daerah dalam mewujudkan misi yang ada diperlukan nilai-nilai yang melandasi jalannya pemerintahan yang baik yaitu transparansi dan akuntabilitas. Misi tersebut dapat terlaksana apabila mengacu juga pada pedoman yang berlaku. Oleh karena itu DPU diharuskan untuk mengikuti peraturan sesuai dengan acuan yang ditentukan yaitu dengan memasukkan unsurunsur format yang ada pada PERMENPAN No 29 Tahun 2010. Tujuannya adalah agar dalam mempertanggungjawabkan hasil evaluasi kinerja dalam satu tahun anggaran DPU bisa lebih transparan dan akuntabel. Demikian untuk mengetahui apakah unsur-unsur yang terdapat dalam format LAKIP DPU sudah sesuai atau tidak dengan PERMENPAN, Maka di buat tabel perbandingan sebagai berikut untuk mengetahui kesesuaian dan ketidaksesuaian yang terdapat pada LAKIP DPU dan PERMENPAN.

Faktor-Faktor Penyebab Ketidaksesuaian Unsur-Unsur LAKIP DPU Kabupaten Minahasa. Pada LAKIP DPU Kabupaten Minahasa dalam hal format penyusunannya ditemukan terdapat beberapa faktor yang menyebabkan unsur-unsur format penyusunan LAKIP tahun 2016 tidak sesuai dengan acuan PERMENPAN tentang pedoman Penyusunan Penetapan Kinerja dan Pelaporan Akuntabilitas Kinerja Instansi Pemerintah sebagai tindak lanjut TAP MPR RI Nomor 28 Tahun 1999 tentang Penyelenggaraan Negara yang Bersih dan Bebas Korupsi, Kolusi, dan Nepotisme. Berdasarkan analisis tersebut, maka di uraikan beberapa faktor yang menyebabkan unsur-unsur format penyusunan LAKIP DPU tidak sesuai dengan PERMENPAN No 29 Tahun 2010. Berdasarkan dari hasil wawancara yang diperoleh dari informan pada DPU Kabupaten Minahasa.

1. Indikator Kinerja Utama (IKU). LAKIP DPU diketahui tidak menyusun bagian IKU sesuai dengan peraturan yang ada. IKU pada LAKIP DPU hanya terdapat pada LAMPIRAN dalam bentuk tabel dan tidak diuraikan secara lengkap. Seperti yang di ungkapkan oleh informan sebagai berikut :

"LAKIP DPU hanya menjabarkan secara singkat tentang IKU pada lampiran, dari tahun ke tahun seperti yang ada dalam dokumen LAKIP DPU tahun 2016 memang tidak mencantumkan bagian IKU dikarenakan format penyusunan LAKIP DPU tahun 2016 hanya mengikuti format penyusunan tahun-tahun sebelumnya".

Pada bagian IKU dalam peraturan tertulis bahwa format bagian penutup IKU pada PERMENPAN terdapat sasaran disertai dengan cara perhitungan untuk mengukur capaian indikator kinerja utama. Sedangkan realisasinya DPU tidak mencantumkan cara perhitungan untuk mengukur capaian indikator sasaran. Itulah yang menjadi salah satu faktor yang menyebabkan perbedaan format pada LAKIP DPU dan PERMENPAN no 29 tahun 2010.

2. Penutup. Pada bab penutup tertulis bahwa format penutup pada PERMENPANno 29 tahun 2010 terdapat strategi pemecahan masalah. Sedangkan realisasinya DPU tidak mencantumkan strategi pemecahan masalah pada bagian penutup. Hal ini juga menjadi salah satu faktor yang menyebabkan perbedaan format pada LAKIP DPU dan PERMENPAN no 29 tahun 2010. Berikut ungkapan dari informan :

"Hal ini dikarnakan pada format penyusunan sebelumnya strategi pemecahan masalah di uraikan pada bab III yaitu akuntabilitas kinerja. Seperti yang ada pada dokumen LAKIP tahun 2016"

Pada bagian penutup hanya ada beberapa indikator kinerja yang harus menjadi perhatian Pemerintah Kabupaten Minahasa dalam peningkatan kinerja tahunan berlaku tidak terdapat uraian permasalahan utama pada bagian ini. Penjelasan tersebut sudah di tuangkan dalam bab pendahuluan. 
3. Lampiran. Adapun faktor ketidaksesuaian yaitu pada bagian lampiran. Pada LAKIP DPU dalam lampiran hanya melampirkan perjanjian kinerja. Dalam LAKIP DPU tidak melampirkan unsur-unsur lampiran lainnya yang terdapat dalam penjelasan peraturan. Sedangkan dalam PERMENPAN terdapat beberapa unsur dalam format lampiran. Berikut ungkapan dari informan :

"Pada dasarnya yang di lampirkan hanya sesuai dengan yg diperlukan oleh atasan, dan di karnakan kurangnya penjelasan yang ada pada PERMENPAN mengenai bagian ini. Jadi pada bagian lampiran dibuat sesuai dengan peraturan dari Bupati."

LAKIP DPU memiliki beberapa Pedoman peraturan lain seperti peraturan dari Bupati. Dalam hal ini bagian lampiran hanya dibuat sesuai dengan peraturan daerah yang ada.

\subsection{Pembahasan}

Dari hasil analisis data secara keseluruhan dapat diketahui bahwa LAKIP DPU Kabupaten Minahasa belum disusun sesuai regulasi pendukung yaitu PERMENPAN No 29 Tahun 2010 tentang Pedoman Penyusunan Penetapan Kinerja dan Pelaporan Akuntabilitas Kinerja Instansi Pemerintah sebagai tindak lanjut TAP MPR RI Nomor XI/MPR/1998 tentang Penyelenggaraan Negara yang bersih dan Bebas Korupsi, Kolusi dan Nepotisme. DPU belum menyusun LAKIP sesuai dengan acuan yang berlaku. Melalui tabel perbandingan antara LAKIP DPU Kabupaten Minahasa dengan PERMENPAN no 29 tahun 2010 dapat diketahui dari sepuluh unsur yang tertulis, terdapat satu yang tidak dipenuhi DPU Kabupaten Minahasa dalam penyusunan LAKIP dan terdapat dua unsur yang berbeda dengan format pada peraturan. Sepuluh unsur tersebut yaitu Ikhtisar Eksekutif, Pendahuluan, Perencanaan dan Perjanjian Kinerja, Akuntabilitas Kinerja, Rencana Strategis, Formulir Rencana Kinerja Tahunan (RKT), Indikator Kinerja Utama (IKU), Formulir Perjanjian Kinerja, Penutup, Lampiran. Satu unsur yang tidak dapat dipenuhi indikator kinerja utama (IKU). Dua unsur yang berbeda dalam peraturan yaitu penutup dan lampiran. DPU tidak mencantumkan IKU pada LAKIP 2016 sesuai dengan acuan yang ada. Hal tersebut disebabkan karna penyusunan LAKIP DPU Tahun 2016 hanya melihat format penyusunan LAKIP yang telah disusun pada tahun-tahun sebelumnya dan tidak melakukan perubahan dalam penyusunan LAKIP dengan melihat acuan pada peraturan yang ada.

\section{KESIMPULAN DAN SARAN}

\subsection{Kesimpulan}

Berikut kesimpulan berdasarkan hasil analisis data Laporan Akuntabilitas Kinerja Instansi Pemerintah (LAKIP) Dinas Pekerjaan Umum Kabupaten Minahasa :

1. DPU dalam penyusunannya telah menyusun sesuai dengan PERMENPAN No 29 Tahun 2010 akan tetapi masih ada unsur-unsur yang belum terpenuhi dan belum sesuai dengan peraturan tersebut.

2. Unsur-unsur format LAKIP yang sudah di jabarkan oleh DPU yaitu pendahuluan, perencanaan dan perjanjian kinerja, akuntabilitas kinerja, rencana strategis, formulir rencana kinerja Tahunan (RKT), indikator kinerja utama (IKU), formulir perjanjian kinerja, penutup, lampiran. Adapun unsur-unsur yang belum dijabarkan yaitu IKU dan yang belum sesuai adalah penutup dan lampiran.

3. Pengimplementasian unsur-unsur format penyusun LAKIP DPU belum terlaksana secara optimal. LAKIP DPU masih memiliki kekurangan-kekurangan yang harus diperbaiki. Kekurangan-kekurangan tersebut disebabkan karena kurangnya informasi tertulis mengenai format penyusunan LAKIP yang digunakan DPU dan keterbatasan pemahaman dari DPU mengenai unsur-unsur format pada LAKIP. Kendala lainnya tidak terdapat tim penyusun LAKIP pada DPU.

4. Seperti yang dijelaskan diatas bahwa ada beberapa faktor yang menyebabkan unsur-unsur format penyusunan LAKIP DPU yang belum sesuai dengan PERMENPAN No 29 Tahun 
2010 tentang Pedoman Penyusunan Penetapan Kinerja dan Pelaporan Akuntabilitas Kinerja Instansi Pemerintah sebagai tindak lanjut TAP MPR RI Nomor XI/MPR/1998 tentang Penyelenggaraan Negara yang bersih dan Bebas Korupsi, Kolusi dan Nepotisme. Tentunya hal ini berdampak pada evaluasi nilai penyusunan LAKIP yang menjadi rendah dan berpengaruh tidak akuntabel.

\subsection{Saran}

Beberapa saran yag diberikan peneliti terkait penelitian ini adalah :

1. LAKIP DPU Kabupaten Minahasa sebaiknya lebih memperhatikan unsur-unsur format penyusunan pada pembuatan LAKIP. Sesuai dengan yang terdapat pada acuan dan tidak hanya berlandaskan pada format penyusunan lakip pada tahun-tahun sebelumnya. Agar LAKIP yang dihasilkan DPU Kabupaten Minahasa lebih Akuntabel.

2. Perlu adanya pengembangan dalam proses pembuatan LAKIP DPU Kabupaten Minahasa diantaranya dengan membuat tim penyusun LAKIP untuk mengatasi beberapa kendala yang terjadi dalam penyusunan LAKIP agar proses penyusunan bisa lebih optimal dan mendapatkan hasil yang maksimal.

\section{DAFTAR PUSTAKA}

Alou, S., Ilat, \& Gamaliel, H. 2017. Pengaruh Kesesuaian Kompensasi, Moralitas Manajemen, dan Keefektifan pengendalian Intern Terhadap Kecenderungan Akuntansi Pada Perusahaan Konstruksi di Manado. Jurnal Riset Akuntansi Going Concern, 12(1). http://ejournal.unsrat.ac.id/index.php/gc/article/view/17146

Ketetapan MPR RI Nomor XI/MPR/1998 tentang Penyelenggaraan Negara yang Bersih dan Bebas Korupsi, Kolusi, dan Nepotisme. Jakarta.

Lewedalu, G., Kalangi, L., \& Warongan, J. (2016). Evaluasi Perusahaan, Penyusunan, dan Penyampaian Laporan Pertanggungjawaban Bendahara Pada Badan Pengelolaan Keuangan dan Aset Daerah Kabupaten Maluku Barat. Jurnal Riset Akuntansi Going Concern, 11(3). https://ejournal.unsrat.ac.id/index.php/gc/article/view/13132

Lembaga Administrasi Negara RI. 2003. Penyusunan Standar Pelayanan Publik. LAN. Jakarta.

Lukito, Penny, Kusumastuti. 2014. Membumikan Transparansi dan Akuntabilitas Kinerja Sektor Publik: Tantangan Demokrasi Ke Depan. PT Gramedia Widiasarana Indonesia. Jakarta.

Mahmud, R., Sondakh, J. J., \& Budiarso, N. S. 2016. Analisis Sistem dan Prosedur Pengeluaran Kas Dengan Menggunakan Uang Persediaan (UP) Pada Dinas Sosial

Mangandar, Febritson. 2012. Analisis Terhadap Penyusunan, Pengukuran, Pengevaluasian Kinerja Pada Kementerian Energi dan Sumber Daya Mineral Tahun 2010 (Perspektif Penerapan Akuntabilitas Instansi Pemerintah). Skripsi. Fakultas Ekonomi Universitas Indonesia. Depok.

Moeheriono. 2012. Pengukuran Kinerja Berbasis Kompetensi. Raja Grafindo Persada. Jakarta.

Santoso, Susan. 2013. Analisis Laporan Akuntabilitas Kinerja pada Dinas Kebudayaan dan Pariwisata Provinsi Sulawesi Utara. Jurnal EMBA: Jurnal Riset Ekonomi, Manajemen, Bisnis dan Akuntansi, 1(4). https://ejournal.unsrat.ac.id/index.php/emba/article/view/2647

Tambariki, B., Karamoy, H., \& Tangkuman, S. (2018). Penggunaan Informasi Finansial dalam Mengukur Kinerja Organisasi Sektor Publik (Studi Pada Puskesmas Bahu). Jurnal Riset Akuntansi Going Concern, 13(03). https://ejournal.unsrat.ac.id/index.php/gc/article/view/20673 
Undang-Undang Republik Indonesia Nomor 28 Tahun 1999 Tentang Penyelenggaraan Negara yang Bersih dan Bebas Korupsi, Kolusi dan Nepotisme. Tambahan Lembaran Negara Republik Indonesia Nomor 3851. Jakarta.

Wulansuci, Perpetua. 2017. Analisis Laporan Akuntabilitas Kinerja Instansi Pemerintah Berdasarkan Peraturan Menteri Negara Pendayagunaan Aparatur Negara dan Reformasi Birokrasi Nomor 29 Tahun 2010 Pada Dinas Pekerjaan Umum dan Perumahan Kabupaten Sleman. Skripsi. Fakultas Ekonomi Universitas Sanata Dharma. Yogyakarta. 